\title{
FASHION DESIGN ON THE BASE OF AN INVESTIGATION OF MINOAN COSTUME AND ART
}

\author{
Angelina Kosinkova-Stoeva \\ Faculty of Technics and Technologies, Trakia University, Bulgaria \\ Graf Ignatiev 38, 8600 Yambol, Bulgaria \\ e-mail: kosinkova@abv.bg
}

\begin{abstract}
The paper presents an investigation of forms, ornaments and colors in Minoan female costume and arts (Minoan, Mycenaean and Aegean artefacts) with a main purpose of their application in contemporary fashion design. The analysis of the studied artefacts shows that the basic silhouette and the shapes of element and pieces, ornaments and colors in Minoan, Mycenaean and Aegean female costume, presented in statuettes, frescoes and jewels, and the ornaments and colors of Minoan, Mycenaean and Aegean frescoes, ceramics, and jewellery can be applied in the design of modern ladies' clothing, jewels and accessories. On the base of the results of the investigation designs of seven fashion ensembles of ladies' dresses in combinations with suitable jewels and bags have been created.
\end{abstract}

Keywords: Minoan civilization, Minoan culture, Minoan costume, Minoan arts, fashion design, lady's dress, jewels, fashion accessories.

\section{INTRODUCTION}

Minoan civilization, the first European civilization, originated on the island of Crete from about 3000-1500 BC. The most significant outbreak of ancient Aegean civilization was discovered by Arthur Evans in the early 20th century [20, 24, 28, 29, 31, 32, 35]. The Minoan culture spread to other ancient Aegean and Balkan civilizations and reached to the today's Bulgarian territory [35], as it is seen in Figure 1, and it is one of reason of the investigation, presented in this paper.

The world of Minoan civilization and culture is a source of beauty and joy. Women had a central place in Minoan society as connectors between people and gods. The frescoes show off pure colors and elegance on the lines. The ladies wore dresses with wide and colorful skirts fitted in the waist and reached to the ground, and the upper part with very deep necklines which open the breasts. The open breast is an expression of the motherhood. The femininity was emphasized by exquisite jewels and hairstyles with playful curls [20, 24, 28, 29, 31, 32, 35].

The paper presents an investigation of forms, ornaments and colors in Minoan female costume and arts with a main purpose of their application in contemporary fashion design.

\section{THE STUDY AND ANALYSIS}

For the reaching of the main aim of the paper about application of characteristics of Minoan costume and arts in the contemporary fashion design forms of elements and pieces, ornaments and colors of Minoan, Mycenaean and Aegean ladies' costumes, presented in statuettes, frescoes and jewels, and ornaments and colors from Minoan, Mycenaean and Aegean frescoes, ceramics and jewels are studied and analyzed.

IRITIE Vol. 7, No. 4, 2019 ISSN 1314-8788 (print), ISSN 1314-8796 (online), doi: 10.15547/artte.2019.04.002 


\section{ART'TE Ipplied Reserer rhes in Technics, Technologies and Bduration Journal of the Faculty of Technics and Technologies, Trakia University https://sites.google.com/a/trakia-uni.bg/artte/}

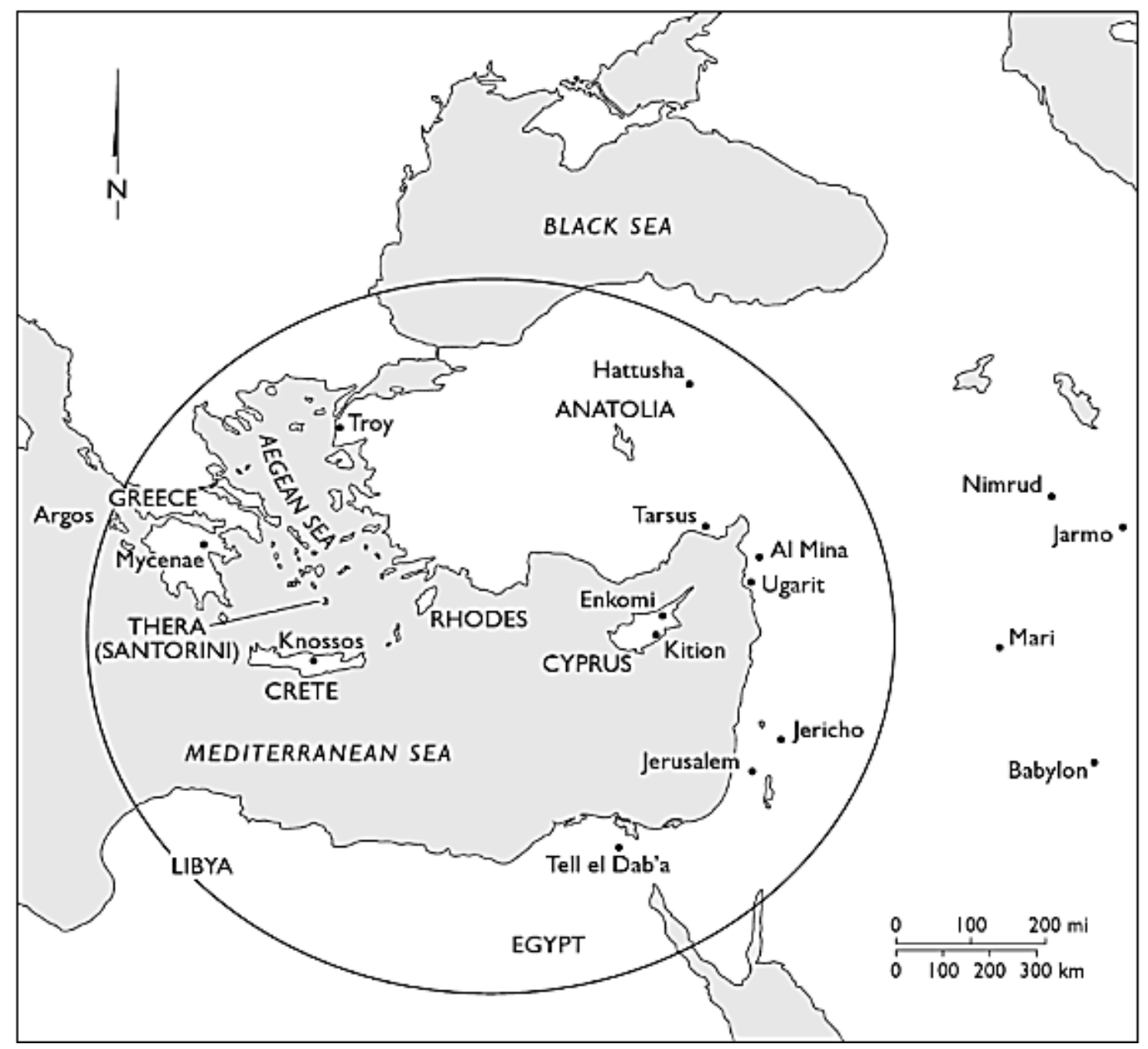

Figure 1. The location of Minoan culture [35]

\subsection{Minoan Female Costume}

The Minoan female costume is the first cutting clothing in the human history. The main characteristics of Minoan female costume are:

- X line or hourglass silhouette $[3,4,6,10,14,16,17,19,20,22,23,24,25,27,28,29$, $30,31,35,37,38,39,40,47,48]$;

- Cone or bell-shaped skirt [3, 4, 6, 10, 14, 16, 17, 19, 20, 22, 23, 24, 25, 27, 28, 29, 30, $31,35,37,38,39,40,47,48]$ with horizontal $[10,16,20,22,24,28,29,31,35,40]$, diagonal $[3,4,14,17,19,23,27,30,37,38,44,47]$ or vertical [24] lines and stripes, squares [10, 16, 20, 22, 24, 28, 29, 31, 35, 40], rhombuses [16, 20, 22, 24, 28, 29, 30, $31,35,40]$, fringe horizontal or diagonal stripes $[3,4,6,10,16,20,22,23,24,27,28,29$, $31,35,40]$. Often the skirt is multi-layered $[3,4,6,16,17,19,20,22,23,24,28,29,30$, 31, 35, 40];

- Fitted upper part, long to the waist or longer with narrow sleeves up to the elbows and deep neck opening, which allows undressing of the breast in rituals. It is considered that the neckline in Minoan dress is bigger than the neck opening in Mycenaean gown [3, 4, $6,10,14,16,17,19,20,22,23,24,25,27,28,29,30,31,35,37,38,39,40,47,48]$;

- Fitting to the waist with a belt $[3,4,6,10,14,16,17,19,20,22,23,24,25,27,28,29$, $30,31,35,37,38,39,40,47,48]$;

IRTIIE Vol. 7, No. 4, 2019 ISSN 1314-8788 (print), ISSN 1314-8796 (online), doi: 10.15547/artte.2019.04.002 


\section{ARTTIE $Y$}

Ipplied Resseirlores in Technics, Technologies and Educration

Journal of the Faculty of Technics and Technologies, Trakia University https://sites.google.com/a/trakia-uni.bg/artte/

- Short apron [16, 20, 22, 24, 28, 29, 31, 35, 40];

- Colors [3, 7, 10, 17, 23, 25, 37, 39, 41, 42, 43, 44, 45, 47, 48]: red, orange, brown, beige, yellow, blue, purple, white and black.

- Hat - high, pointed, beret, turban, triangular, with decoration - feathers, ribbons, etc. [16, 20, 22, 24, 28, 29, 31, 35, 40];

- Hair decorations [10, 24, 25];

- Golden jewels - necklaces, earrings, rings [4, 10, 15, 16, 24, 25, 40].

\subsection{ANALYSIS}

The analysis of the artefacts shows that forms, ornaments and colors, which can be applied in the contemporary fashion design are:

- From Minoan, Mycenaean and Aegean costume:

- X silhouette;

- Forms of pieces and elements: skirt, apron, neckline;

- Multi layers;

○ Fringe;

- Geometric ornaments: horizontal, diagonal or vertical stripes, squares, rhombuses;

- Colors: saturated and soft tones of red, orange, brown, beige, yellow, blue, purple, white and black.

- From jewels, frescoes and ceramics:

- Geometric ornaments [5, 9, 10, 13, 16, 17, 21, 24, 32, 36, 40, 44, 45]: wavy lines, spirals;

- Floral ornaments $[1,2,7,8,9,10,11,12,15,17,18,19,24,27,36,38,39,40,43$, 45, 46, 47]: lilies, sea daffodils, irises, crocuses, saffron, pomegranate, olive branches, other plants, stylized flowers and leaves;

- Animal ornaments [4, 7, 9, 10, 15, 16, 21, 26, 32, 36, 40, 43, 45]: butterflies, bees, swallows, other birds, dolphins, fish, octopuses;

- Colors (except for jewellery, which is mainly golden) [7, 8, 9, 10, 15, 21, 32, 39, 41, $42,43,44,45,47]$ : saturated and soft tones of red, orange, brown, beige, yellow, blue, purple, white and black.

\section{FASHION DESIGN}

A study of the application of Minoan costume and arts in the contemporary fashion shows that they are used by based in London Greek designer Mary Katrantzou in her collection Spring 2017 [33, 34]. Any other application of Minoan costume and art haven't found and this is another reason about their investigation with main aim their using in fashion design.

Figures from 2 to 8 present seven fashion ensembles of ladies' dresses in combinations with suitable jewels and bags, which are inspired by Minoan costume and art, and are created with application of the results of their investigation, presented in this paper.

Figure 2 shows a design of a lady's dress in X line which combines one colored upper part with a multi-coloured skirt in cone silhouette. The neck opening is deep in rectangular form with Minoan motifs. The short sleeves accent to the deep neckline. The skirt is multi-layered one as the first layer is detachable as an apron. To the ensemble a bag with triangle decoration and a necklace with stylized lilies are added. Figure 2 presents some of artefacts which give ideas for presented design: a Mycenaean necklace with stylized lilies from Mycenaean collection of National Archaeological Museum of Athens [10], the Minoan "Snake Goddess" from Knossos Palace, Crete, one of the most important Minoan artefacts, which can be seen in Heraklion Archaeological Museum [16, 20, 22, 24, 28, 29, 31, 35, 40], and a

IRTIIE Vol. 7, No. 4, 2019 ISSN 1314-8788 (print), ISSN 1314-8796 (online), doi: 10.15547/artte.2019.04.002 


\section{ARTTIE $Y$}

Ipplied Resseirlores in Technics, Technologies and Educration

Journal of the Faculty of Technics and Technologies, Trakia University https://sites.google.com/a/trakia-uni.bg/artte/

reconstruction of a Mycenaean lady, which original is from Mycenaean collection of National Archaeological Museum of Athens [10].

Figure 3 presents a design of a lady's dress, which expresses the feel of lightness, fun and movement of Minoan women. The $X$ line dress is with not only multi-layered cone skirt, but multi-layered sleeves too around a deep rectangle neckline. An apron with stylized flowers and spirals is added to the dress. The ensemble is completed with a necklace with stylized flower and a diadem with feathers. Figure 3 shows three of artefacts, which are inspiration of the presented design: the Prince with Lilies, maybe the most famous Minoan artefact, a fresco from the Knossos Palace with current location in Heraklion Archaeological Museum [15], a golden plate with stylized flowers and spiral lines [24], and one of the Minoan "Snake Goddesses" from Knossos Palace, Crete, which can be seen in Heraklion Archaeological Museum [16].

Figure 4 presents a design of a lady's dress, inspired by the most famous Minoan "Snake Goddess" from Knossos [16, 20, 22, 24, 28, 29, 31, 35, 40], shown in Figure 4 too. Like the dress of the Goddess the contemporary design is with a multi-layered bell-shaped skirt, which expresses the femininity. The elegancy of the skirt is accented with the multi-colored squares and the small apron with rhombuses. The whole elegance of the model is underlined by a big striped square neckline. The ensemble is completed with a small bag in form of a dolphin, inspired by dolphins in a Minoan pottery [40] and a fresco from Knossos Palace [21, 32], presented in Figure 4.

Figure 5 shows a design of a lady's multi-layered dress with not too wide bell-shaped skirt. The layers, the neckline and the sleeves hem line are designed in diagonal directions. Figure 5 presents two of artefacts, which have inspired the dress design: the diagonal lines from the dress of Minoan Princess from a fresco in Knossos Palace [25], and the multi-layered in diagonal direction skirt of a lady from Akrotiri, Santorini [37]. The ensemble is completed with a necklace with a form of famous Minoan bees earing, which can be seen in Heraklion Archaeological Museum [16, 40].

Figure 6 presents a design of an asymmetrical lady's dress. The asymmetric skirt is with horizontal layers. The decoration of the deep triangle neck opening and the peplum of the dress, and the earrings are stylized lilies, one of the most used floral ornaments in Minoan culture. The ensemble is completed with a bag in form of an octopus. Figure 6 shows and some of the artefacts, which give the ideas for the presented design: a necklace with stylized lilies [24], a statue of a young Minoan lady with a layered skirt, an artefact, which can be seen in Cleveland Museum of Art [14], Minoan pottery with lilies from Crete [40] and Knossos storage jar with octopuses, which can be seen in Ashmolean Museum of Art and Archaeology [26].

Figure 7 shows a design of a lady's dress with multi-colored multi-layered skirt with an apron with an iris, one of the most beautiful floral ornaments in the Minoan culture. The neckline form underlines the idea for femininity. This idea is expresses in the full ensemble with the bracelet in the form of snake and the small bag with an iris. Some of artefacts, which have inspired this design, are presented in Figure 6 too: the most famous Minoan "Snake Goddess" from Knossos [16, 20, 22, 24, 28, 29, 31, 35, 40], a beautiful lady with irises from Akrotiri, Santorini [47], and maybe the most famous Minoan artifact of the Prince with Lilies from Knossos [15].

Figure 8 present a design with a lady's dress with fringe stripes from Minoan dresses and crocuses, one of the most used floral ornaments in Minoan ceramics and frescoes and a small bag with fringe. Some of artifacts, which give the ideas for the design, are: a fresco with crocuses from Knossos [1, 2, 8], a Minoan ceramic figure of a dress with crocuses [3, 11,12 ], and s lady with a skirt with diagonal fringe stripes from Akrotiri, Santorini [3].

All designs of ladies' dresses are in colors of Minoan and Mycenaean costumes and arts frescoes and ceramics.

IRTIIE Vol. 7, No. 4, 2019 ISSN 1314-8788 (print), ISSN 1314-8796 (online), doi: 10.15547/artte.2019.04.002 


\section{ART'TIE Y}
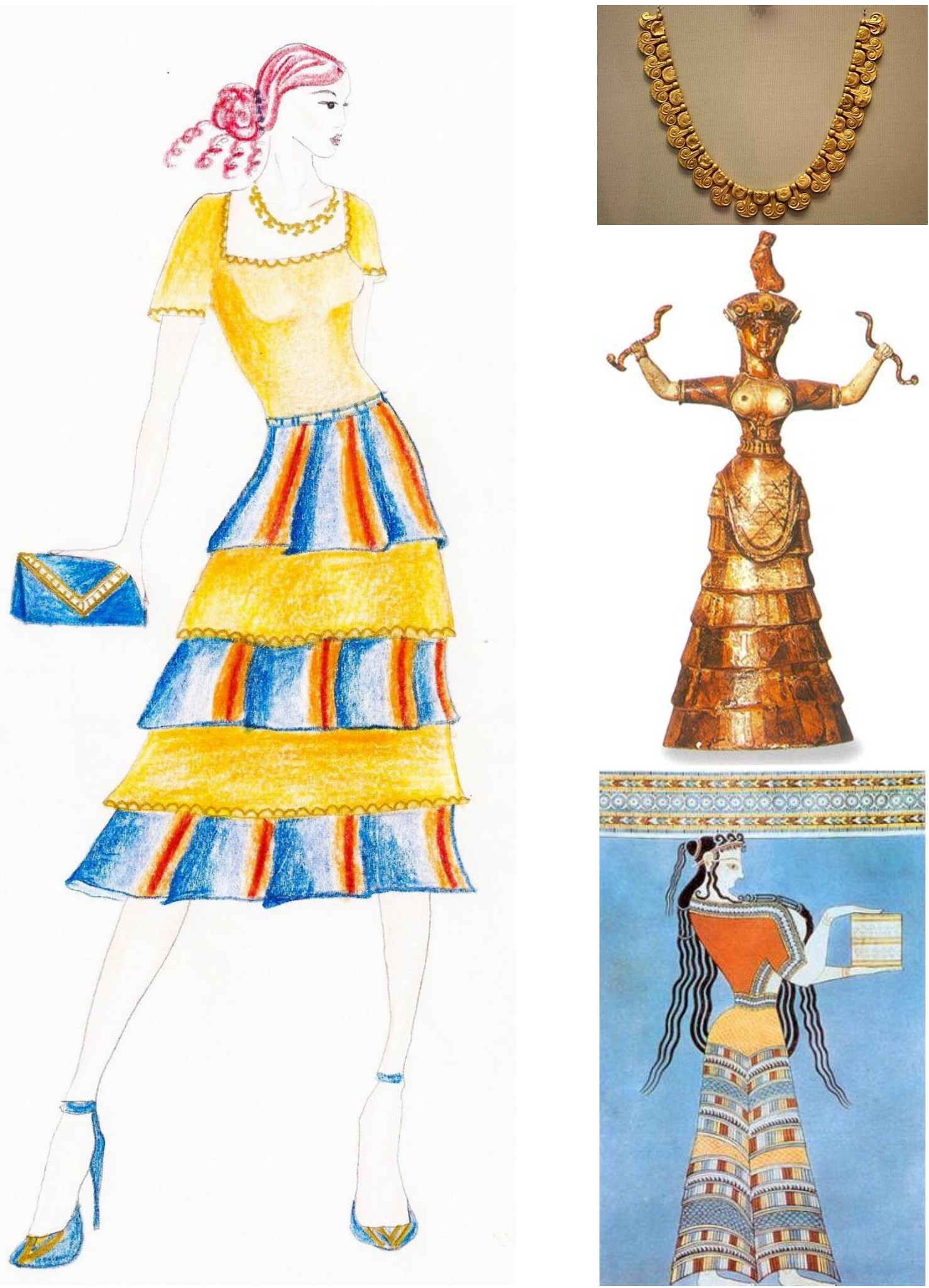

Figure 2.

A lady's dress, a bag and a necklace and some of Minoan and Mycenaean artefacts [10, 16, $20,22,24,28,29,31,35,40]$ by which the presented designs have been inspired

IRTIIE Vol. 7, No. 4, 2019 ISSN 1314-8788 (print), ISSN 1314-8796 (online), doi: 10.15547/artte.2019.04.002 


\section{ART'IIE Y}
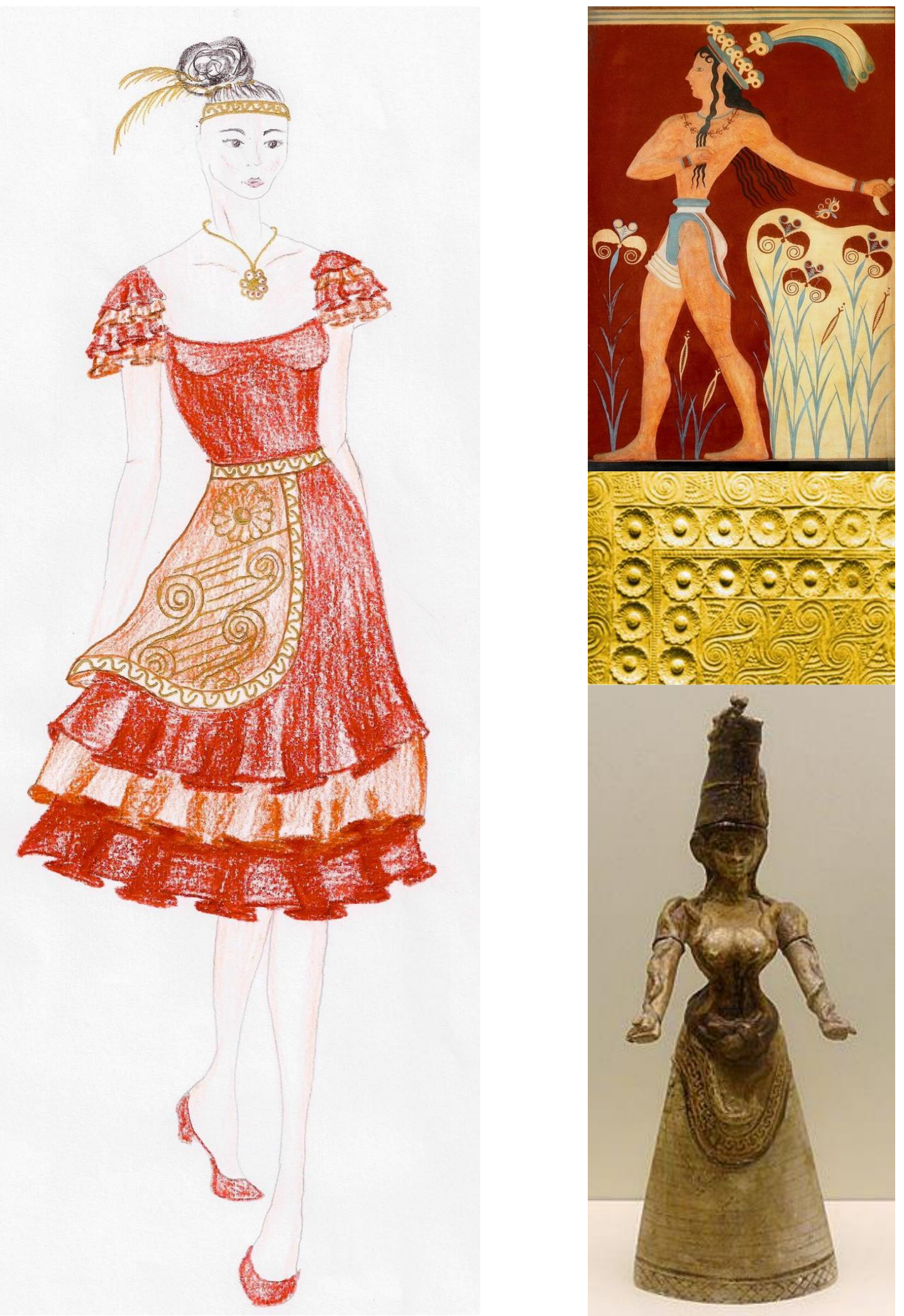

Figure 3. A lady's dress, a necklace and hair decorations and some of Minoan artefacts $[15,16,24]$ by which the presented designs have been inspired

IRTIIE Vol. 7, No. 4, 2019 ISSN 1314-8788 (print), ISSN 1314-8796 (online), doi: 10.15547/artte.2019.04.002 


\section{ARTITE Y M}
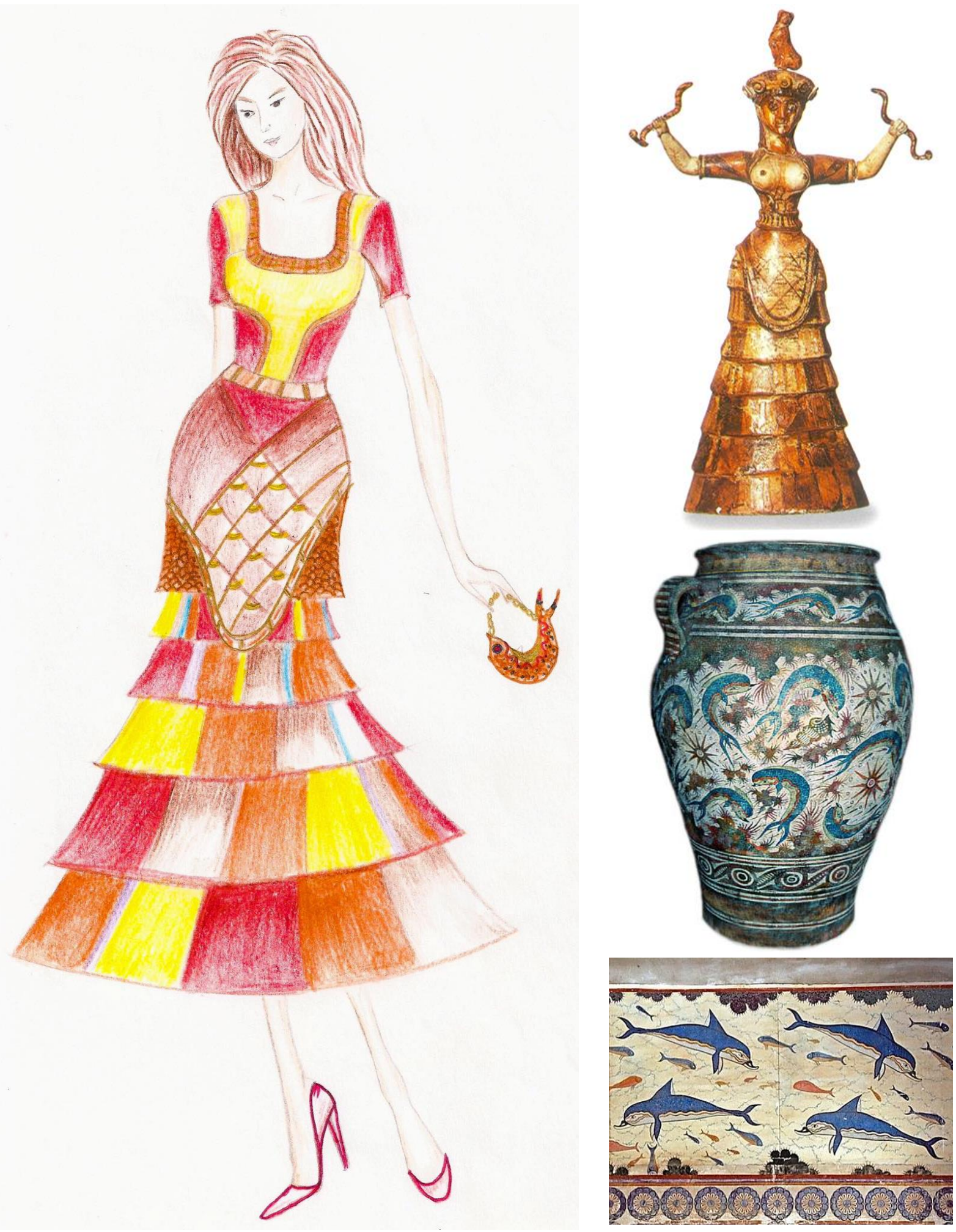

Figure 4.

A lady's dress and a small bag and some of Minoan artefacts [16, 20, 21, 32, 22, 24, 28, 29, $31,35,40]$ by which the presented designs have been inspired

IRTIIE Vol. 7, No. 4, 2019 ISSN 1314-8788 (print), ISSN 1314-8796 (online), doi: 10.15547/artte.2019.04.002 


\section{ARTITIE Y}
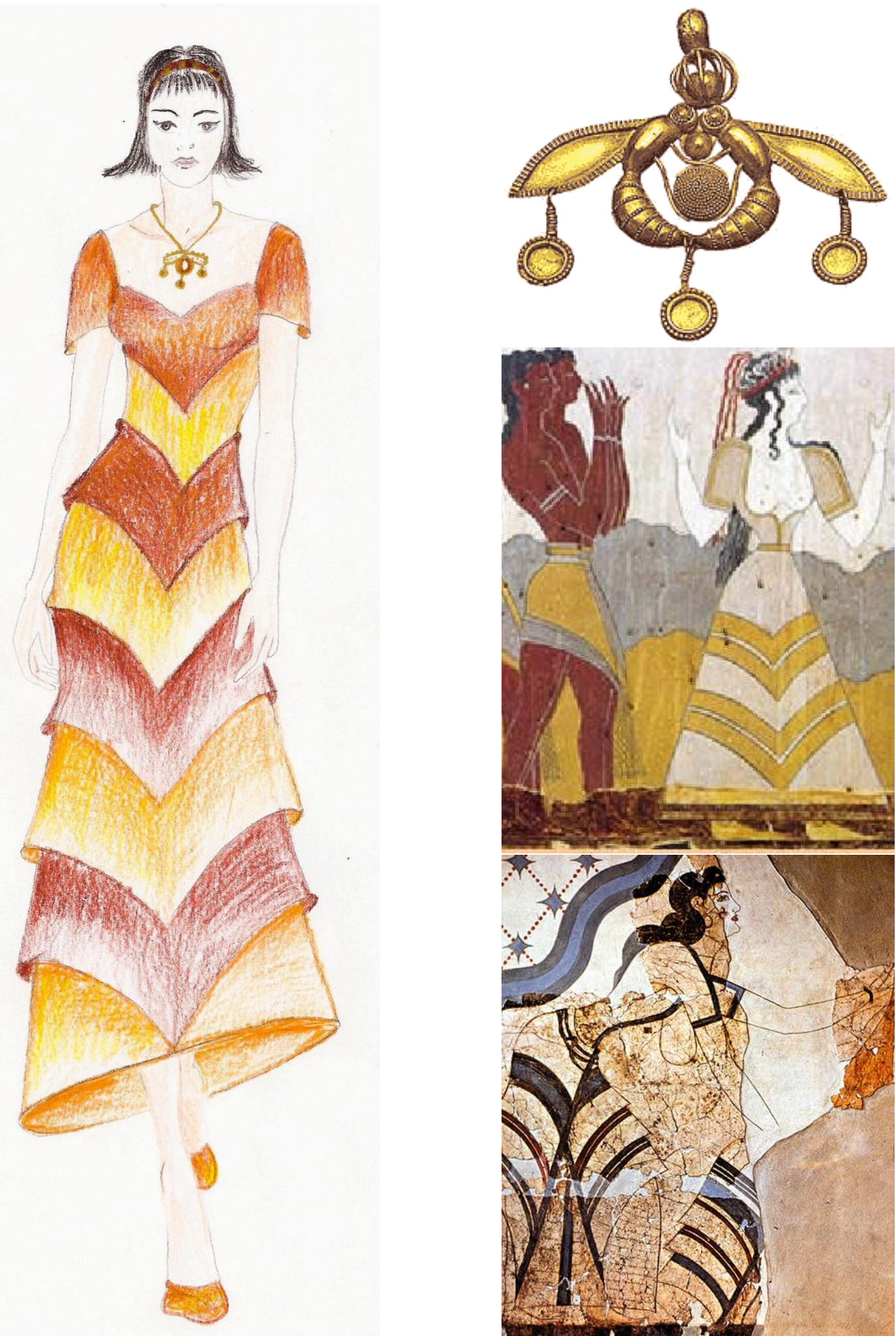

Figure 5.

Design of a lady's dress, a bag and a necklace and some of Minoan and Aegean artefacts $[16,25,37,40]$ by which the presented designs have been inspired

IRTIIE Vol. 7, No. 4, 2019 ISSN 1314-8788 (print), ISSN 1314-8796 (online), doi: 10.15547/artte.2019.04.002 


\section{ART'TIE}

Ipplied Researreches in Technics, Technologies and Eductation

Journal of the Faculty of Technics and Technologies, Trakia University https://sites.google.com/a/trakia-uni.bg/artte/
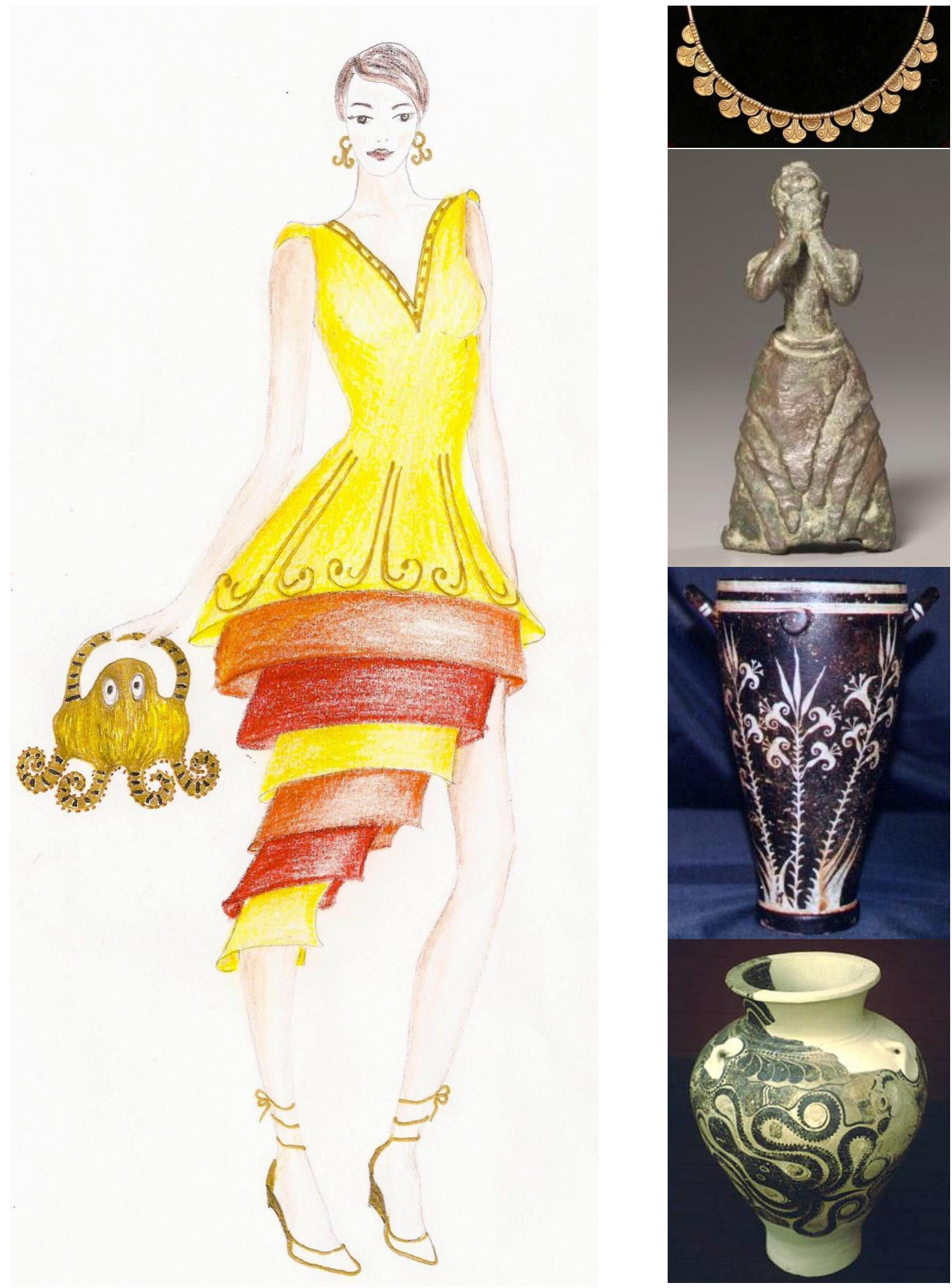

Figure 6.

Design of a lady's dress, a bag and a necklace and some of Minoan artefacts [14, 24, 26, 40] by which the presented design have been inspired

IRTIIE Vol. 7, No. 4, 2019 ISSN 1314-8788 (print), ISSN 1314-8796 (online), doi: 10.15547/artte.2019.04.002 


\section{ARTITE Y M}
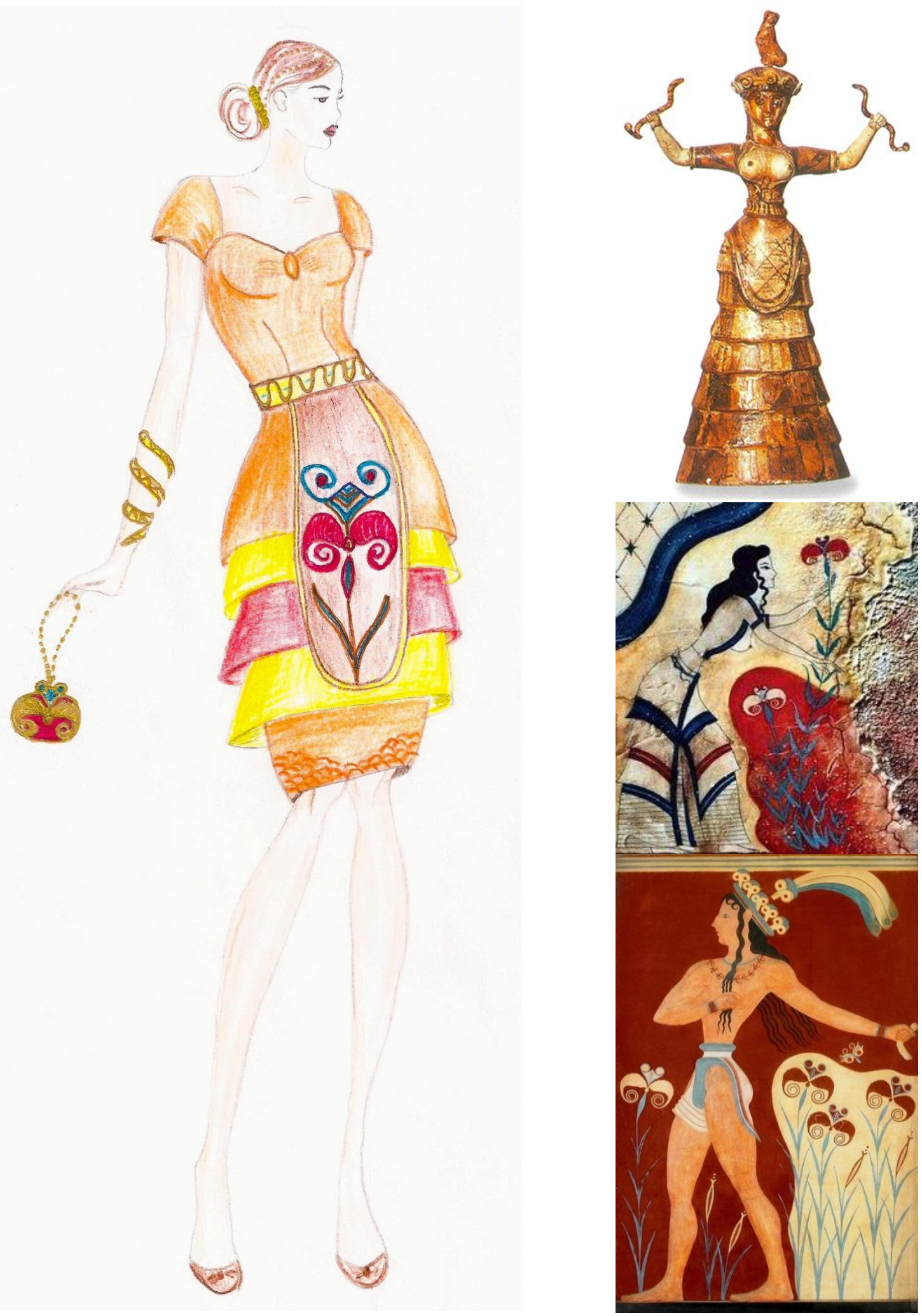

Figure 7. Design of a lady's dress, a bag and a necklace and some of Minoan and Aegean artefacts $[15,16,20,22,24,28,29,31,35,40,47]$ by which the presented designs have been inspired

IRTIIE Vol. 7, No. 4, 2019 ISSN 1314-8788 (print), ISSN 1314-8796 (online), doi: 10.15547/artte.2019.04.002 


\section{ARTIIE Y}
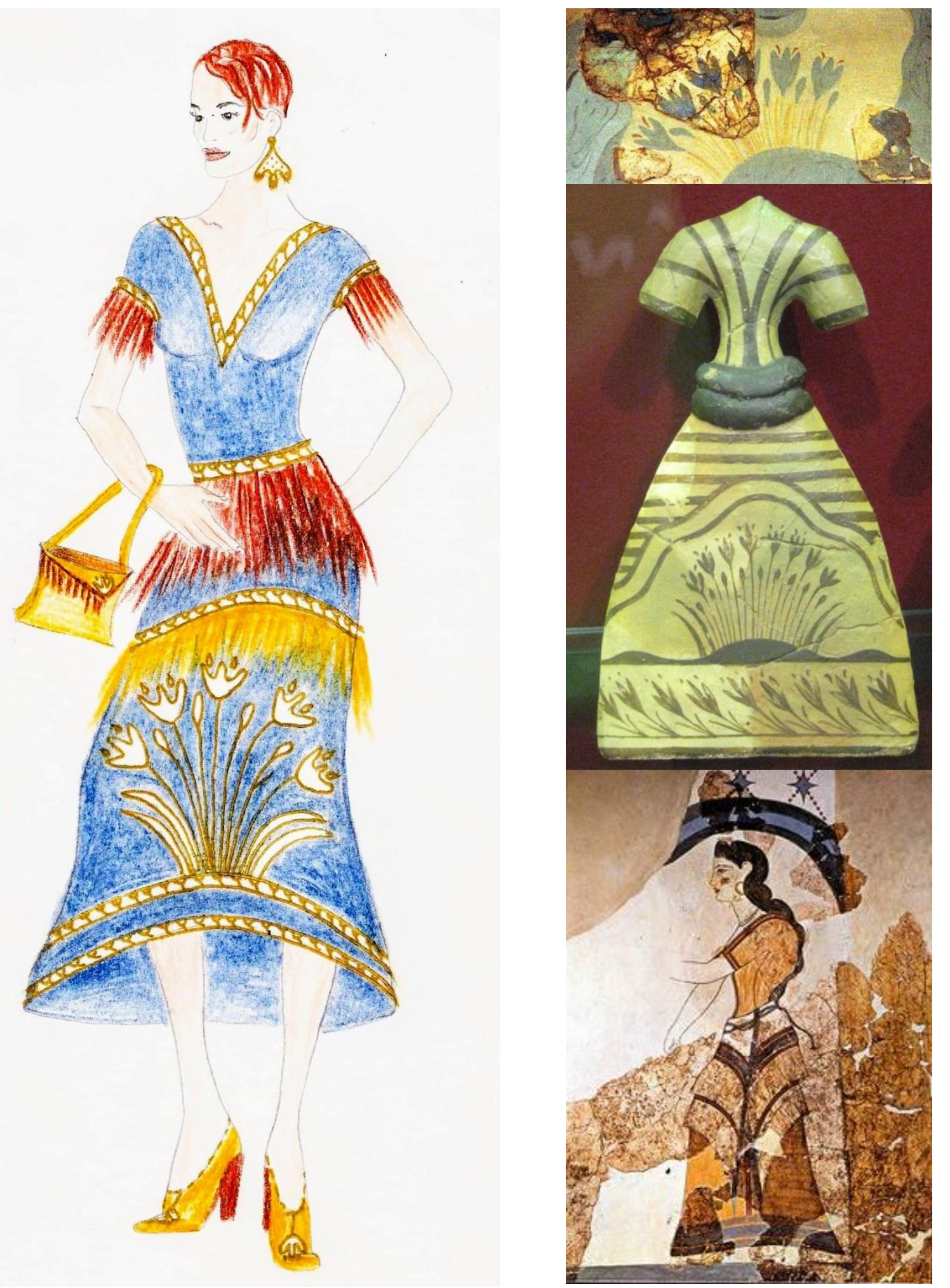

Figure 8.

Design of a lady's dress, a bag and a necklace and some of Minoan and Aegean artefacts $[1,2,3,8,11,12]$ by which the presented designs have been inspired

IRTIIE Vol. 7, No. 4, 2019 ISSN 1314-8788 (print), ISSN 1314-8796 (online), doi: 10.15547/artte.2019.04.002 


\section{CONCLUSION}

The presented contemporary fashion designs adapt forms, ornaments and colors from Minoan female costume and ornaments and colors from arts in Minoan culture (Minoan, Mycenaean and Aegean artefacts) to the contemporary woman and her being and feeling. All presented dresses and accessories express by their forms the femininity. The saturated and soft colors give safetygiving security and at the same time cheerfulness and affirmation. The contemporary woman, like the woman from the ancient Crete culture is in the center of the society and will not lose her taste for the elegant and comfortable, which has come back centuries.

\section{REFERENCES}

[1] Beckmann S. (2012).Beyond the Moon: Minoan 'Calendar'-Symbolism in the 'Blue Bird Fresco'. Living the Lunar Calendar, pp. 1-16.

[2] Beckmann S. (2014). An 'agricultural calendar' from the Bronze Age. Explaining and Exploring Diversity in Agricultural Technology. Oxford Books. ISBN 978-1-78297-021-7.

[3] Blakolmer F. (2012). Body Marks and Textile Ornaments in Eegean Iconography: Their Meaning and Symbolism. Kosmos. Jewellery, Adornment and Textiles in the Aegean Bronze Age. Proceedings of the 13th International Aegean Conference/ 13e Rencontre égéenne internationale, University of Copenhagen, Danish National Research Foundation's Centre for Textile Research, 21-26 April 2010. Aegaeum: Annales liégeoises et PASPiennes d'archéologie égéenne, Vol. 33, pp. 325-333.

[4] Blakolmer F. (2016). II Buono, il Brutto, il Cattivo? Character, Symbolism and Hierarchy of Animals and Supernatural Creatures in Minoan and Mycenaean Iconography. Creta Antica, Vol. 17, pp. 97-184.

[5] Borgna E. (2013). Cult and Crafts at Late Minoan Phaistos: a New Clay Female Figure

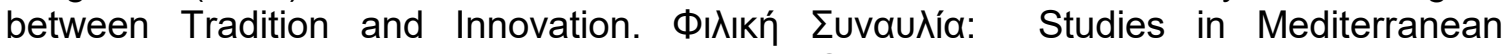
Archaeology for Mario Benzi. BAR International Series 2460, pp. 39-48.

[6] Budin S. L. (2014) Mother or sister? Finding adolescent girls in Minoan figural art. In S. Morrow and A. Kieburg (eds) Mädchen im Altertum/Girls in Antiquity, pp.105-116.

[7] Chapin A. P. (1997). A Re-Examination of the Floral Fresco from the Unexplored Mansion at Knossos. The Annual of the British School at Athens, Vol. 92, pp. 1-24. http://www.jstor.org/stable/30103475.

[8] Chapin A. P. and Shaw M. C. (2006). The Frescoes from the House of the Frescoes at Knossos: A Reconsideration of Their Architectural Context and a New Reconstruction of the Crocus Panel. The Annual of the British School at Athens, Vol. 101, pp. 57-88. http://www.jstor.org/stable/30073256.

[9] Collection of Antiquities of Thera. National Archaeological Museum of Athens. https://www.namuseum.gr/en/collection/syllogi-archaiotiton-thiras/.

[10] Collection of Mycenaean Antiquities. National Archaeological Museum of Athens. https://www.namuseum.gr/en/collection/syllogi-mykinaikon-archaiotiton/.

[11] Day J. (2011). Crocuses in Context. A Diachronic Survey of the Crocus Motif in the Aegean Bronze Age. Hesperia: The Journal of the American School of Classical Studies at Athens, Vol. 80, pp. 337-379.

[12] Dewan R. (2015). Bronze Age Flower Power: The Minoan Use and Social Significance of Saffron and Crocus Flowers. Chronika: Journal of Institute for European and $\begin{array}{lllll}\text { Mediterranean } \quad \text { Archaeology. } & \text { Vol. 2015, } & \text { 42-55. }\end{array}$ http://www.chronikajournal.com/resources/Dewan\%202015.pdf.

[13] Egan E. C. (2012). Cut from the Same Cloth: The Textile Connection between Palace Style Jars and Knossian Wall Paintings. Kosmos. Jewellery, Adornment and Textiles in

IRIIIE Vol. 7, No. 4, 2019 ISSN 1314-8788 (print), ISSN 1314-8796 (online), doi: 10.15547/artte.2019.04.002 


\section{IRTITE}

Ipplied Resseirlores in Technics, Technologies and Educration Journal of the Faculty of Technics and Technologies, Trakia University https://sites.google.com/a/trakia-uni.bg/artte/

the Aegean Bronze Age. Proceedings of the 13th International Aegean Conference/ 13e Rencontre égéenne internationale, University of Copenhagen, Danish National Research Foundation's Centre for Textile Research, 21-26 April 2010. Aegaeum: Annales liégeoises et PASPiennes d'archéologie égéenne, Vol. 33, pp. 317-324.

[14] Female Worshiper. The Cleveland Museum of Art. https://www.clevelandart.org/art/2002.89?f\%5B0\%5D=field_collection:826\&f\%5B1\%5D= field_images_field_large_image_url:1.

[15] Fresco of the "Lily Prince". Heraklion Archaeological Museum. http://odysseus.culture.gr/h/4/eh430.jsp?obj_id=7914.

[16] Heraklion Archaeological Museum. https://www.heraklion.gr/en/ourplace/archeologicalmuseum/archeological-museum.html.

[17] Günkel-Maschek U. (2012). Spirals, Bulls, and Sacred Landscapes: The Meaningful Appearance of Pictorial Objects within their Spatial and Social Contexts. Minoan Realities Approaches to Images, Architecture, and Society in the Aegean Bronze Age. Aegis 05, pp. 115-139.

[18] Günkel-Maschek U. (2012). Reflections on the Symbolic Meaning of the Olive Branch as Head-Ornament in the Wall Paintings of Building Xeste 3, Akrotiri. Kosmos. Jewellery, Adornment and Textiles in the Aegean Bronze Age. Proceedings of the 13th International Aegean Conference/ 13e Rencontre égéenne internationale, University of Copenhagen, Danish National Research Foundation's Centre for Textile Research, 2126 April 2010. Aegaeum: Annales liégeoises et PASPiennes d'archéologie égéenne, Vol. 33, pp. 361-367.

[19] Günkel-Maschek U. (2016). Establishing the Minoan 'Enthroned Goddess' in the Neopalatial Period: Images, Architecture, and Elitist Ambition. Metaphysis. Ritual, Myth and Symbolism in the Aegean Bronze Age. Aegaeum: Annales liégeoises et PASPiennes d'archéologie égéenne, Vol. 39, pp. 255-262.

[20] Janson H. W., Janson A. F. (2005). History of Art. Vol. 1, Bulgaria, Elementi. ISBN 9549414-01-9. (In Bulgarian).

[21] Jarus O. (2017). Knossos: Palace of the Minoans. Life Science. https://www.livescience.com/27955-knossos-palace-of-the-minoans.html.

[22] Jones B. (2001). The Minoan "Snake Goddess". New Interpretation of Her Costume and Identity. Aegaeum: Annales liégeoises et PASPiennes d'archéologie égéenne, Vol. 22, pp. 259-264.

[23] Jones B. R. (2014). Revisiting the Figures and Landscapes on the Frescoes at Hagia Triada. Physis: L'environnement naturel et la relation homme-milieu dans le monde égéen protohistorique Actes de la 14e Rencontre égéenne internationale, Paris, Institut National d'Histoire de l'Art (INHA), 11-14 décembre 2012. Aegaeum: Annales liégeoises et PASPiennes d'archéologie égéenne, Vol. 37, pp. 493-497.

[24] Kazlacheva Z., Ilieva J. (2014). History of Costume and Fashion. Stara Zagora, Bulgaria, Trakia University. ISDN 978-954-338-101-2. (In Bulgarian).

[25] Kay Ph. (2011). The Realm of Minos. https://phillipkay.wordpress.com/2011/01/29/therealm-of-minos/.

[26] Knossos Storage Jar. Ashmolean Museum of Art and Archaeology. University of Oxford. https://www.ashmolean.org/knossos-storage-jar.

[27] Konstantinidi-Syvridi E. (2012). A Fashion Model of Mycenaean Times: The Ivory Lady from Prosymna. Kosmos. Jewellery, Adornment and Textiles in the Aegean Bronze Age. Proceedings of the 13th International Aegean Conference/ 13e Rencontre égéenne internationale, University of Copenhagen, Danish National Research Foundation's Centre for Textile Research, 21-26 April 2010. Aegaeum: Annales liégeoises et PASPiennes d'archéologie égéenne, Vol. 33, pp. 265-270. 
[28] Laver J. (2010). Costume and Fashion. A Concise History. London, Thames and Hudson world of art. ISBN 978-0-500-20348-4.

[29] Laveyrie-Dagen N., Balouet J.-Ch. (2004). History of Clothing: Encyclopedia Larousse. Bulgaria, Icon. ISBN 954-8517-16-7.

[30] Lenuzza V. (2012). Dressing Priestly Shoulders: Suggestions from the Campstool Fresco. Kosmos. Jewellery, Adornment and Textiles in the Aegean Bronze Age. Proceedings of the 13th International Aegean Conference/ 13e Rencontre égéenne internationale, University of Copenhagen, Danish National Research Foundation's Centre for Textile Research, 21-26 April 2010. Aegaeum: Annales liégeoises et PASPiennes d'archéologie égéenne, Vol. 33, pp. 255-263.

[31] Leonard J. (2019). The Bedrock of Civilization. Greece is. Crete. Summer 2019, pp. 6471. http://www.greece-is.com/greece-crete-2019/.

[32] Leonard J. (2019). Knossos Uncovered. Greece is. Crete. Summer 2019, pp. 72-77. http://www.greece- is.com/greece-crete-2019/.

[33] Mary Katrantzou: de-codes https://thegreekdesigners.com/2017/04/02/mary-katrantzou-de-codes-minoan-figure/.

[34] Mary Katrantzou. Spring 2017. https://www.marykatrantzou.com/collections/spring-summer-2017/.

[35] Marinatos N. (2013). Minoan Kingship and the Solar Goddess: A Near Eastern Koine. University of Illinois Press, ISBN 978-0252079672.

[36] Masseti M. (1997). Representation of Birds in Minoan Art. International Journal of Osteoarchaeology, Vol. 7, pp. 354-363.

[37] Muge A., Loukovikos M. (2013). Minoan Cretan Thalassocracy. https://peripluscd.wordpress.com/2013/03/04/chronicle-2-minoan-cretan-thalassocracy2/.

[38] Paschalidis C. (2012). Reflections of Eternal Beauty. The Unpublished Context of a Wealthy Female Burial from Koukaki, Athens and the Occurrence of Mirrors in Mycenaean Tomb. Kosmos. Jewellery, Adornment and Textiles in tb he Aegean Bronze Age. Proceedings of the 13th International Aegean Conference/ 13e Rencontre égéenne internationale, University of Copenhagen, Danish National Research Foundation's Centre for Textile Research, 21-26 April 2010. Aegaeum: Annales liégeoises et PASPiennes d'archéologie égéenne, Vol. 33, pp. 547-556.

[39] Saffron - The history of the world's most expensive spice. https://crocussativus.eu/en/geschiedenis-saffraan.

[40] The Minoans: Craftsmanship. http://antiquatedantiquarian.blogspot.com/2015/04/theminoans-craftsmanship.html.

[41] Vlachopoulos A. and Sotiropoulou S. (2012). The Blue Colour on the Akrotiri WallPaintings: From the Palette of the Theran Painter to the Laboratory Analysis. Talanta. Proceedings of the Dutch Archaeological and Historical Society. Vol. XLIV, pp. 245-272.

[42] Vlachopoulos A. and Zorzos L. (2014). Physis and Techne on Thera: Reconstructing Bronze Age Environment and Land-Use Based on New Evidence from Phytoliths and the Akrotiri Wall-Paintings. Aegaeum: Annales liégeoises et PASPiennes d'archéologie égéenne. Vol. 37, pp. 183-196.

[43] Vlachopoulos A. and Georma F. (2012). Jewellery and Adornment at Akrotiri, Thera: The Evidence from the Wall Paintings and the Finds. Kosmos. Jewellery, Adornment and Textiles in the Aegean Bronze Age. Proceedings of the 13th International Aegean Conference/ 13e Rencontre égéenne internationale, University of Copenhagen, Danish National Research Foundation's Centre for Textile Research, 21-26 April 2010. Aegaeum: Annales liégeoises et PASPiennes d'archéologie égéenne, Vol. 33, pp. 3541.

IRTIIE Vol. 7, No. 4, 2019 ISSN 1314-8788 (print), ISSN 1314-8796 (online), doi: 10.15547/artte.2019.04.002 


\section{ARTTE $Y$}

Ipplied Resseirl'hes in Technics, Technologies and Educration Journal of the Faculty of Technics and Technologies, Trakia University https://sites.google.com/a/trakia-uni.bg/artte/

[44] Vlachopoulos A. (2016). Images of Physis Or Perceptions of Metaphysis? Some Thoughts on the Iconography of the Xeste 3 Building At Akrotiri, Thera. Ritual, Myth and Symbolism in the Aegean Bronze Age. Aegaeum: Annales liégeoises et PASPiennes d'archéologie égéenne, Vol. 39, pp. 375-384.

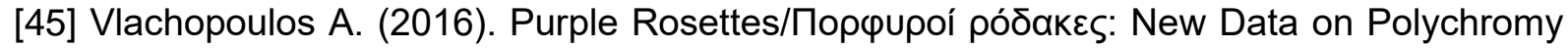
and Perception in the Thera Wall Paintings. Studies in Aegean Art and Culture. A New York Aegean Bronze Age Colloquium in Memory of Ellen N. Davis, pp. 59-75.

[46] Wesołowska M. (2017). Human Life Hidden in the Symbol of a Flower between the Minoan World and Egypt. Sympozjum Egejskie. Papers in Aegean Archaeology, Vol. 1, pp. 79-83.

[47] Were the Minoans "flower children" living among lilies? https://www.nooz.gr/entertainment/1530104/itan-oi-minwites-paidia-twn-loyloydiwn-poyzoysan-anamesa-se-krina.

[48] Whittaker H. (2012). Some Reflections on the Use and Meaning of Colour in Dress and Adornment in the Aegean Bronze Age. Kosmos. Jewellery, Adornment and Textiles in the Aegean Bronze Age. Proceedings of the 13th International Aegean Conference/ 13e Rencontre égéenne internationale, University of Copenhagen, Danish National Research Foundation's Centre for Textile Research, 21-26 April 2010. Aegaeum: Annales liégeoises et PASPiennes d'archéologie égéenne, Vol. 33, pp. 193-198. 